\title{
Association of Interleukin 10 Haplotype with Low Bone Mineral Density in Korean Postmenopausal Women
}

\author{
Byung Lae Park ${ }^{8, \dagger}$, In Kwon Han ${ }^{\S \S}$, Ho Sa Lee \\ Joon-Shik Shin", Shin-Yoon Kim"l and Hyoung Doo Shin ${ }^{\S, *}$ \\ ${ }^{\S}$ Department of Genetic Epidemiology, SNP Genetics, Inc., 11th Floor, Maehun B/D, \\ 13 Chongro $4 \mathrm{Ga}$, Chongro Gu, Seoul 110-834, Korea \\ ${ }^{\S \S}$ Department of Internal Medicine, School of Medicine, SungKyunKwan University, Samsung Cheil Hospital, \\ 1-19, Mookjung-dong, Chung-Gu, Seoul 100-380, Korea \\ 'Department of Biology, Research Institute of Basic Science, Kyung Hee University, \\ 1 Hoegi-dong, Dongdaemun-Gu, Seoul 130-701, Korea \\ "Department of Obstetrics \& Gynecology, College of Medicine, The Catholic University of Korea, \\ Banpo-dong, Seocho-Gu, Seoul 137-701, Korea \\ "Institute Hospital of Jaseng Oriental Medicine \& Jaseng-Bio Corp., \\ 635 Shinsa-dong, Kangnam-ku, Seoul 135-896, Korea \\ "Department of Orthopedic Surgery, Skeletal Disease Genome Research Center, \\ Kyungpook National University hospital, San-Keuk-dong, Bukgu, Daegu 702-701, Korea
}

Received 16 April 2004, Accepted 9 June 2004

Osteoporosis is a disease characterized by exaggerated loss of bone mass, with as much as 50 to $85 \%$ of the variation in bone mineral density (BMD) commonly accepted as being genetically determined. Although intensive studies have attempted to elucidate the genetic effects of polymorphisms on BMD and/or osteoporosis in several genes, the genes involved are still largely unknown. The possible associations of genetic variants in five-candidate genes (IL10, CCR3, $M C P 1, M C P 2$ and $G C$ ) with spinal BMD were investigated in Korean postmenopausal women $(n=370)$. Fourteen SNPs in five candidate genes were genotyped, and the haplotypes of each gene constructed. The associations of adjusted spinal BMD by age, year since menopause (YSM) and body mass index (BMI), with genetic polymorphisms, were analyzed using multiple regression models. Genetic association analysis of Korean postmenopausal women revealed that $I L 10-592 A>C$ and/or $I L 10 h t 2$ were associated with decreased bone mass, whereas no significant associations were observed with all polymorphisms in other genes. The levels of spinal BMD in individuals bearing the ILIO -592CC genotype were lower $(0.78 \pm 0.16)$ than those in others $(0.85 \pm 0.17)(P=0.02)$, and the BMD of $I L 10 h t 2$ bearing individuals were also lower $(0.82 \pm 0.15)$ than those in others $(0.85 \pm 0.17)(P=0.04)$. Our results suggest that variants of

*To whom correspondence should be addressed.

Tel: 82-2-3675-2186; Fax: 82-2-3675-2189

E-mail: hdshin@snp-genetics.com
ILIO might play a role in the decreased BMD, although additional study might need to be followed-up in a more powerful cohort.

Keywords: Bone mineral density, Haplotype, Interleukin 10, Osteoporosis, Single nucleotide polymorphism

\section{Introduction}

Osteoporosis is a common systemic skeletal disease, defined as both a decrease in bone mass and strength, which increases the fracture risk. Recent studies have shown that osteoporosis is strongly associated with genetic components and genetic factors, which play major roles in the development of peak bone mass, with hereditability accounting for about 50-85\% of the variance in bone mass. This was supported by twin studies showing a much higher concordance of bone mineral density (BMD) in monozygotic than dizygotic twins (Slemenda et al., 1991; Kanis et al., 1994; Young et al., 1995; Arden and Spector 1997; Eisman 1999; Stewart and Ralston 2000). Numerous candidate genes and their genetic variants, including estrogen receptor $(E R)$, transforming growth factor beta1 (TGFB1), Interleukin-1 receptor antagonist (ILIRA), Interleukin6 (ILO), collagen 1A1 (COLIAl) and osteoprotegerin (OPG), (Kobayashi et al., 1996; Murray et al., 1997; Keen et al., 1998; Yamada et al., 2001; Arko et al., 2002; Garcia- 
Giralt et al., 2002), have been proposed and implicated as genetic markers for BMD, since Morrison and his colleagues reported that vitamin $\mathrm{D}$ receptor $(V D R)$ gene polymorphism was involved in bone metabolism (Morrison et al., 1992; Morrison et al, 1994). Although these intensive studies attempted to elucidate these genetic effects of polymorphisms for BMD and/or osteoporosis, the genes involved are still largely unknown.

Interleukin 10 (IL10) is a potent anti-inflammatory and a powerful $\mathrm{T}_{\mathrm{H}} 2$ cell cytokine. It is produced by various cells, such as $\mathrm{T}_{\mathrm{H}} 2$ cells, eosinophils and lymphoid cells, and its roles involved inhibiting both replication of macrophage/monocyte and T-cell lymphocyte and the secretion of inflammatory cytokines (IL1, TNFA, IL6, IL8 and IL12) (de Waal Malefyt et al., 1992; Wanidworanun and Strober 1993; Roth et al., 1996; Groux et al., 1997; Asseman and Powrie, 1998). IL10 down-regulates the expressions of MHC-I and -II molecules and the production of $\mathrm{T}_{\mathrm{H}} 1$ cytokines, as well as promotes $\mathrm{B}$ cell activation, regulates immunoglobulin class switching and maintains B cell viability by inhibiting apoptosis (Moore et al., 1993) . IL10 thus regulates both cellular and hormonal immune responses, so IL10 significantly regulates various diseases, like autoimmune disease, AIDS and chronic hepatitis $\mathrm{C}$ infection. IL10 polymorphisms in the promoter regions (-1082 $G>A,-819 C>T$ and $-592 A>C$ ) and their haplotype combination (Rees et al., 2002) may also affect IL10 levels, and have been demonstrated to play an important role in association with various diseases (Eskdale et al., 1998; Shin et al., 2000; Vidigal et al., 2002). It was recently found that IL10 suppresses osteoblastic differentiation in mouse bone marrow cultures (Van Vlasselaer et al., 1993; Van Vlasselaer et al., 1994), and exerts a reciprocal action on the differentiation of osteoclasts and macrophages from their shared precursor. This potent inhibition of osteoclast formation by IL10 suggests that IL10 might play a role in the modulation of bone loss in inflammatory disorders (Owens et al., 1996).

CCR3, a chemokine receptor, and MCP1 and MCP2, chemotactic cytokines are involved in immune responses. Abnormal T-cell expression of several chemokine receptors, including CCR3, and the levels of soluble chemokines in the plasma/serum were observed in patients with SLE (Eriksson et al., 2003). In recent studies, several polymorphisms of $C C R 3, M C P 1$ and $M C P 2$ were identified and their association with several diseases, such as asthma, fibrosis and HCV examined (Fukunaga et al., 2001; Szalai et al., 2001; Hellier et al., 2003). However, the association of the polymorphisms of these three genes with the BMD and/or osteoporosis has not been established. Vitamin D plays a major role in calcium homeostasis and bone turnover, and vitamin $\mathrm{D}$ binding protein (group specific component $(G C)$, alternatively $D B P$ ) may play an important role as both a major protein for the vitamin D metabolites and osteoclast differentiation, as well as implicate an association between the polymorphism of vitamin-D binding protein and osteoporosis by bone loss or resorption
(Adebanjo et al., 1998). The polymorphisms in Vitamin D binding protein were reported to be associated with lumbar spine BMD, BMI, plasma DBP, IGF-1 and femoral neck BMD (Rapado et al., 1999).

In this study, five genes (IL10, CCR3, MCPI, MCP2 and $G C$ ) were selected as candidates for BMD levels, and whether genetic polymorphisms in the ILIO gene are associated with spinal BMD in Korean postmenopausal women investigated.

\section{Materials and Methods}

Subjects Blood samples were obtained, with informed consent, from 370 Korean postmenopausal women who visited the Samsung Cheil hospital for routine check-ups. The DNA was collected from blood samples, as described in Kim et al. $(2003)$. The mean $( \pm$ SD) age, height, weight and spinal BMD of subjects in the study were $54.86( \pm 6.54), 155.24( \pm 4.70), 55.30( \pm 6.82)$ and $0.84( \pm 0.17)$, respectively. The BMI (body mass index) was then calculated using the following formula: BMI = weight $(\mathrm{kg}) /[\text { height }(\mathrm{m})]^{2}$. The spinal BMD of each participant was measured by dual energy X-ray absorptiometry (DEXA, Lunar Pixi, USA). The device was calibrated twice daily using a standard BMD phantom provided by the manufacturer. The precision error of the device was $1.2 \%$.

Genotyping by single base extension (SBE) PCR was performed under touch down conditions (Schunck et al., 1995). For genotyping of polymorphic sites, the amplification and extension primers were designed for single-base extension (SBE) (Vreeland et al., 2002; Zhang and Li, 2003). Primer extension reactions were performed with the SNaPshot ddNTP Primer Extension Kit (Applied Biosystems, Foster City, USA). Information regarding the primers is summarized in Table 1. To clean up the primer extension reaction, one unit of SAP (shrimp alkaline phosphatase) was added to the reaction mixture and incubated at $37^{\circ} \mathrm{C}$ for $1 \mathrm{~h}$, followed by $15 \mathrm{~min}$ at $72^{\circ} \mathrm{C}$ for enzyme inactivation. The DNA samples, containing extension products, and Genescan $120 \mathrm{Liz}$ size standard solutions were added to Hi-Di formamide (Applied Biosystems), according to the recommendation of the manufacturer. The mixture was incubated at $95^{\circ} \mathrm{C}$ for $5 \mathrm{~min}$, followed by $5 \mathrm{~min}$ on ice, and then electrophoresis was performed using the ABI Prism 3100 Genetic Analyzer. The results were analyzed using the ABI Prism GeneScan and Genotyper program (Applied Biosystems).

Statistics The Lewontin's D' (|D'|) between all pairs of biallelic loci were examined (Hedrick 1987; Hedrick and Kumar 2001). Haplotypes of each individual were inferred using the algorithm developed by Stephens et al. (2001) (PHASE), which uses a Bayesian approach incorporating a priori expectations of a haplotypic structure from population genetics and coalescent theory. The genetic effects of inferred haplotypes were analyzed in the same way as the polymorphisms. Means and standard deviations (SD) of the phenotypes, as well as the $P$ values were calculated by multiple regression analyses controlling for age (continuous value) YSM, and BMI as co-variables. 
Table 1. Sequences of amplifying and extension primers for genotyping of the polymorphisms of the ILIO, CCR3, MCP1, MCP2 and $G C$ genes by the single-base extension method

\begin{tabular}{|c|c|c|c|}
\hline Gene & Locus* & & Sequences \\
\hline \multirow[t]{12}{*}{ ILIO } & \multirow[t]{3}{*}{$-1082 A>G$} & Forward & 5'-CCAACTGGCTCCCCTTACCTTCTAC-3' \\
\hline & & Reverse & 5'-CAGGATTCCATGGAGGCTGG-3' \\
\hline & & Extension & 5'-АСТТТССТСТТАССТАТСССТАСТТСССС-3' \\
\hline & \multirow[t]{3}{*}{$-819 T>C$} & Forward & 5'-GGGTGAGGAAACCAAATTCTCAG-3' \\
\hline & & Reverse & 5'-GGTAGTGCTCACCATGACCCC-3' \\
\hline & & Extension & 5'-GTACCCTTGTACAGGTGATGTAA-3' \\
\hline & \multirow[t]{3}{*}{$-592 A>C$} & Forward & 5'-AGGTGGAAACATGTGCCTGAG-3' \\
\hline & & Reverse & 5'-CTCAAAGTTCCCAAGCAGCC-3' \\
\hline & & Extension & 5'-TTCCATTTTACTTTCCAGAGACTGGCTTCCTACAG-3' \\
\hline & \multirow{3}{*}{$+3930 T>C$} & Forward & 5'-ATAGCTGACCCAGCCCCTT-3' \\
\hline & & Reverse & 5'-AAATCGTTCACAGAGAAGCTCAGT-3' \\
\hline & & Extension & 5'-GCTCAGTAAATAAATAGAAATGGGGGTTGAGGTATCAGAGGTAATAAATATTCTAT-3' \\
\hline \multirow[t]{12}{*}{$C C R 3$} & \multirow[t]{3}{*}{$-22557 G>A$} & Forward & 5'-GTAGGTGTCGCTTTTCCAG-3' \\
\hline & & Reverse & 5'-TGGCCCCATACTACCTCTA-3' \\
\hline & & Extension & 5'-AATCAATGATGATGGTCCAGGCAGGTGGAAGTA-3' \\
\hline & \multirow[t]{3}{*}{$-520 T>G$} & Forward & 5'-TGACAGGAGAAATGGACATGG-3' \\
\hline & & Reverse & 5'-TACTGTCTCTTACGGCATTTTGC-3' \\
\hline & & Extension & 5'-TATAATCAATGATGATCAATTTCCCCATTAACTATAATGAATG-3' \\
\hline & \multirow[t]{3}{*}{$-174 C>T$} & Forward & 5'-ACCCCACAACATTTCTGCT-3' \\
\hline & & Reverse & 5'-CCTTCGTAAAACACACCAGTT-3' \\
\hline & & Extension & 5'-ATTATAATCAATGATGATGCATATCAGAGGTGCCAGGA-3' \\
\hline & \multirow{3}{*}{$\begin{array}{c}+51 T>C \\
(Y 17 Y)\end{array}$} & Forward & 5'-GGGAGAAGTGAAATGACAACCT-3' \\
\hline & & Reverse & 5'-AAGAGGCCCACAGTGAACAC-3' \\
\hline & & Extension & 5'-TTGAGACCTTTGGTACCACATCCTACTA-3' \\
\hline \multirow[t]{6}{*}{$M C P 1$} & \multirow[t]{3}{*}{$-2518 G>A$} & Forward & 5'-TGGGAATTTCCACTCACTTC-3' \\
\hline & & Reverse & 5'-CCAGGACTAGAGACTGTGCAA-3' \\
\hline & & Extension & 5'-AGAAGTGGGAGGCAGACAGCT-3' \\
\hline & \multirow[t]{3}{*}{$-2076 A>T$} & Forward & 5'-TGGGAATTTCCACTCACTTC-3' \\
\hline & & Reverse & 5'-CCAGGACTAGAGACTGTGCAA-3' \\
\hline & & Extension & 5'-AAGTTCATGGTAAAGGATGCACTAAC-3' \\
\hline \multirow[t]{3}{*}{$M C P 2$} & \multirow{3}{*}{$\begin{array}{c}+1311 A>C \\
(K 46 Q)\end{array}$} & Forward & 5'-CTTCACCTAAGGACCAAGGGCT-3' \\
\hline & & Reverse & 5'-TCTCAGTCCATGTATGAAGGCTCA-3' \\
\hline & & Extension & 5'-TCCCCCACAGCTTCAAGACC-3' \\
\hline \multirow[t]{9}{*}{$G C$} & \multirow{3}{*}{$\begin{array}{c}+27279 T>C \\
(C 283 C)\end{array}$} & Forward & 5'-CATTCGTTTTGTAGCTGCCTGA-3' \\
\hline & & Reverse & 5'-ACATCTTTGTTTGTGGGCAACTC-3' \\
\hline & & Extension & 5'-GATGATGACAATTTATCCACAAAGAATTCTAAGTTTGAAGACTG-3' \\
\hline & \multirow{3}{*}{$\begin{array}{c}+31417 T>G \\
(D 416 E)\end{array}$} & Forward & 5'-GACTGGCAGAGCGACTA-3' \\
\hline & & Reverse & 5'-TCATTGCAAAGACAGCCAAG-3' \\
\hline & & Extension & 5'-TCATGATTATAATCAATGATGATAGAGCGACTAAAAGCAAAATTGCCTGA-3' \\
\hline & \multirow{3}{*}{$\begin{array}{c}+31428 C>A \\
(T 420 K)\end{array}$} & Forward & 5'-GACTGGCAGAGCGACTA-3' \\
\hline & & Reverse & 5'-TCATTGCAAAGACAGCCAAG-3' \\
\hline & & Extension & 5'-ATAATCAATGATGATAGCTTGTTAACCAGCTTTGCCAGTTCC-3' \\
\hline
\end{tabular}

* Calculated from transcriptional start site in promoter region $(I L 10-1082 A>G, I L 10-819 T>C, I L 10-592 A>C, M C P 1-2518 G>A$, and $M C P 1-2076 A>T)$, and from translational start site $(C C R 3-22557 G>A, C C R 3-520 T>C, C C R 3-174 C>T, C C R 3+51 T>C(Y 17 Y)$, $M C P 2+1311 A>C(K 46 Q), G C+27279 T>C(C 283 C), G C+31417 T>C(D 416 E)$, and $G C+31428 C>A(K 420 T))$.

\section{Results}

The rare allele frequencies of each SNP were 0.083 (IL10 $-1082 A>G), 0.309$ (IL10 -819T > C), 0.312 (IL10 -592A >
C), $0.038($ IL10 +3930T > C $), 0.261(C C R 3-22557 \mathrm{G}>\mathrm{A})$, $0.401(C C R 3-520 \mathrm{~T}>\mathrm{G}), 0.360(C C R 3-174 \mathrm{C}>\mathrm{T}), 0.036$ $(C C R 3+51 T>C(Y 17 Y)), 0.340(M C P 1-2518 G>A), 0.058$ $(M C P 1-2076 A>T), 0.280(M C P 2+1311 A>C(K 46 Q))$, 
Table 2. Frequencies of single nucleotide polymorphisms (SNPs) in the IL10, CCR3, MCP1, MCP2 and GC genes in the Korean population $(\mathrm{n}=370)$

\begin{tabular}{|c|c|c|c|c|c|c|c|}
\hline Gene & Locus & Region & & enoty & & Frequency* & Heterozygosity \\
\hline \multirow[t]{8}{*}{ ILIO } & \multirow[t]{2}{*}{$-1082 A>G$} & \multirow[t]{2}{*}{ Promoter } & A & $\mathrm{AG}$ & $\mathrm{G}$ & \multirow[t]{2}{*}{0.089} & \multirow[t]{2}{*}{0.162} \\
\hline & & & 305 & 57 & 4 & & \\
\hline & \multirow[t]{2}{*}{$-819 T>C$} & \multirow[t]{2}{*}{ Promoter } & $\mathrm{T}$ & $\mathrm{CT}$ & $\mathrm{C}$ & \multirow[t]{2}{*}{0.309} & \multirow[t]{2}{*}{0.427} \\
\hline & & & 177 & 148 & 38 & & \\
\hline & \multirow[t]{2}{*}{$-592 A>C$} & \multirow[t]{2}{*}{ Promoter } & A & $\mathrm{AC}$ & C & \multirow[t]{2}{*}{0.309} & \multirow[t]{2}{*}{0.427} \\
\hline & & & 177 & 148 & 38 & & \\
\hline & \multirow{2}{*}{$+3930 T>C$} & \multirow[t]{2}{*}{ 3'UTR } & $\mathrm{T}$ & $\mathrm{CT}$ & $\mathrm{C}$ & \multirow[t]{2}{*}{0.040} & \multirow{2}{*}{0.076} \\
\hline & & & 339 & 27 & 1 & & \\
\hline \multirow[t]{8}{*}{ CCR3 } & \multirow[t]{2}{*}{$-22557 G>A$} & \multirow[t]{2}{*}{ Intron1 } & G & $\mathrm{AG}$ & A & \multirow[t]{2}{*}{0.263} & \multirow[t]{2}{*}{0.388} \\
\hline & & & 201 & 139 & 27 & & \\
\hline & \multirow[t]{2}{*}{$-520 T>G$} & \multirow[t]{2}{*}{ Intron3 } & $\mathrm{T}$ & GT & G & \multirow[t]{2}{*}{0.405} & \multirow[t]{2}{*}{0.482} \\
\hline & & & 131 & 178 & 61 & & \\
\hline & \multirow[t]{2}{*}{$-174 C>T$} & \multirow[t]{2}{*}{ Intron3 } & $\mathrm{C}$ & $\mathrm{CT}$ & $\mathrm{T}$ & \multirow[t]{2}{*}{0.364} & \multirow[t]{2}{*}{0.463} \\
\hline & & & 146 & 179 & 45 & & \\
\hline & \multirow{2}{*}{$\begin{array}{c}+51 T>C \\
(Y 17 Y)\end{array}$} & Exon4 & $\mathrm{T}$ & $\mathrm{CT}$ & $\mathrm{C}$ & 0.038 & 0.073 \\
\hline & & & 341 & 28 & 0 & & \\
\hline$M C P 1$ & $-2518 G>A$ & Promoter & G & AG & A & 0.349 & 0.455 \\
\hline & & & 139 & 102 & 51 & & \\
\hline & $-2076 A>T$ & Promoter & A & $\mathrm{AT}$ & $\mathrm{T}$ & 0.063 & 0.150 \\
\hline & & & 312 & 41 & 2 & & \\
\hline$M C P 2$ & $+1311 A>C$ & Exon3 & A & $\mathrm{AC}$ & $\mathrm{C}$ & 0.282 & 0.405 \\
\hline & $(K 46 Q)$ & & 192 & 139 & 33 & & \\
\hline$G C$ & $+27279 T>C$ & Exon8 & $\mathrm{T}$ & $\mathrm{CT}$ & $\mathrm{C}$ & 0.109 & 0.194 \\
\hline & $(C 283 C)$ & & 293 & 70 & 5 & & \\
\hline & $+31417 T>G$ & Exon11 & $\mathrm{T}$ & GT & $\mathrm{G}$ & 0.248 & 0.373 \\
\hline & $(D 416 E)$ & & 185 & 122 & 20 & & \\
\hline & $+31428 C>A$ & Exon11 & $\mathrm{C}$ & $\mathrm{AC}$ & A & 0.221 & 0.345 \\
\hline & $(T 420 K)$ & & 173 & 76 & 22 & & \\
\hline
\end{tabular}

*Frequencies of rare alleles.

$0.107(G C+27279 T>C(C 283 C)), 0.262(G C+31417 T>G$ $(D 416 E))$ and $0.218(G C+31428 C>A(T 420 K))$ in the Korean population (Table 2). Haplotypes were constructed in each gene, and common haplotypes (freq. > 0.03) were used in further analysis (Table 3). Four haplotypes in IL10, three in $M C P 2$ and four in $G C$ were observed. In $C C R 3$, four major haplotypes concerning over $99.6 \%$ of the distribution were also shown, but the minor haplotypes were excluded. Coefficients of linkage disequilibrium $\left(\left|\mathrm{D}^{\prime}\right|\right)$ of all pair-wise SNPs in each gene were also calculated (Table 4). Haplotypes with either equivalence to single polymorphisms or frequencies less than $3 \%$ were excluded inform the statistical analysis.

The associations of polymorphisms in the IL10, CCR3, $M C P 1, M C P 2$ and $G C$ genes with spinal BMD were analyzed in Korean postmenopausal women $(\mathrm{n}=370)$. The summary of the statistical analysis is shown in Table 5. The genotype and haplotype distributions, means and standard deviations (SD) of spinal BMDs and $P$ values of the three alternative analyzing models (co-dominant, dominant, and recessive) for regression analyses are also shown.
IL10 $-592 A>C$ and IL10 ht2 (A-C-C-T) showed an association with the decrease of spinal BMD $(P=0.02-0.07)$, whereas no significant associations were showed in the other polymorphisms and haplotypes of the CCR3, MCP1, MCP2 and $G C$ genes. The $I L 10-592 A>C$ showed an association with spinal BMD, i.e., the levels of spinal BMD in individuals bearing the ILIO $-592 C C$ genotype were lower $(0.78 \pm 0.16)$ than those in the others $(0.85 \pm 0.17)(P=0.03$ in recessive model). IL10 ht2 (A-C-C-T) also showed an association, i.e., the levels of BMD in IL10 ht 2 bearing individuals were lower $(0.82 \pm 0.15)$ than those in the others $(0.85 \pm 0.16)(P=0.03$ in dominant model).

\section{Discussion}

Osteoporosis is a multifactorial disease, with great impact on morbidity and mortality mainly in postmenopausal women. Although factors related to life-style and habits are recognized may influence bone mass formation, leading to greater or 
Table 3. Frequencies of haplotypes constructed in the $I L 10, C C R 3, M C P 1$ and $G C$ genes in Korean population (n=370)

\begin{tabular}{|c|c|c|c|c|c|c|}
\hline \multirow{2}{*}{$\frac{\text { Gene }}{\text { IL10 }}$} & \multirow[t]{2}{*}{ Haplotype } & \multicolumn{4}{|c|}{ Locus } & \multirow[t]{2}{*}{ Frequency } \\
\hline & & $-1082 A>G$ & $-819 T>C$ & $-592 A>C$ & $+3930 T>C$ & \\
\hline & $h t 1(\mathrm{~A}-\mathrm{T}-\mathrm{A}-\mathrm{T})$ & $\mathrm{A}$ & $\mathrm{T}$ & $\mathrm{A}$ & $\mathrm{T}$ & 0.689 \\
\hline & $h t 2(\mathrm{~A}-\mathrm{C}-\mathrm{C}-\mathrm{T})$ & A & $\mathrm{C}$ & $\mathrm{C}$ & $\mathrm{T}$ & 0.221 \\
\hline & $h t 3(\mathrm{G}-\mathrm{C}-\mathrm{C}-\mathrm{C})$ & G & $\mathrm{C}$ & $\mathrm{C}$ & $\mathrm{C}$ & 0.040 \\
\hline & $h t 4$ (G-C-C-T) & G & $\mathrm{C}$ & $\mathrm{C}$ & $\mathrm{T}$ & 0.050 \\
\hline \multirow[t]{5}{*}{$C C R 3$} & & $-22557 G>A$ & $-520 T>G$ & $-174 C>T$ & $+51 T>C(Y 17 Y)$ & \\
\hline & $h t 1$ (G-T-C-T) & $\mathrm{G}$ & $\mathrm{T}$ & $\mathrm{C}$ & $\mathrm{T}$ & 0.600 \\
\hline & $h t 2(\mathrm{~A}-\mathrm{G}-\mathrm{T}-\mathrm{T})$ & A & G & $\mathrm{T}$ & $\mathrm{T}$ & 0.224 \\
\hline & $h t 3$ (G-G-T-T) & G & G & $\mathrm{T}$ & $\mathrm{T}$ & 0.136 \\
\hline & $h t 4$ (A-G-C-C) & A & G & $\mathrm{C}$ & $\mathrm{C}$ & 0.036 \\
\hline \multirow[t]{5}{*}{$M C P 1$} & & $-2518 G>A$ & $-2076 A>T$ & & & \\
\hline & $h t 1$ (G-A) & $\mathrm{G}$ & $\mathrm{A}$ & & & 0.662 \\
\hline & $h t 2(\mathrm{~A}-\mathrm{A})$ & A & A & & & 0.278 \\
\hline & $h t 3(\mathrm{~A}-\mathrm{T})$ & A & $\mathrm{T}$ & & & 0.060 \\
\hline & & $\begin{array}{c}+27279 T>C \\
(C 283 C)\end{array}$ & $\begin{array}{c}+31417 T>G \\
(D 416 E)\end{array}$ & $\begin{array}{c}+31428 C>A \\
(T 420 K)\end{array}$ & & \\
\hline \multirow[t]{4}{*}{$G C$} & $h t 1$ (T-T-C) & $\mathrm{T}$ & $\mathrm{T}$ & $\mathrm{C}$ & & 0.373 \\
\hline & $h t 2$ (T-T-A) & $\mathrm{T}$ & $\mathrm{T}$ & A & & 0.232 \\
\hline & $h t 3$ (T-G-C) & $\mathrm{T}$ & G & $\mathrm{C}$ & & 0.273 \\
\hline & $h t 4$ (C-T-C) & $\mathrm{C}$ & $\mathrm{T}$ & $\mathrm{C}$ & & 0.122 \\
\hline
\end{tabular}

There were no ambiguous haplotypes phasing due to absolute LD $\left(\left|\mathrm{D}^{\prime}\right|=1\right.$ and $\left.d^{2}=1\right)$ and/or complete $\mathrm{LD}\left(\left|\mathrm{D}^{\prime}\right|=1\right.$ and $\left.d^{2} \neq 1\right)$ between the SNPs in the IL10, MCPI and GC genes. IL10 -819 and IL10 -592 are in absolute LD $\left(d^{2}=1\right)$. IL10 -1082, (IL10 -819: IL10 -592) and $I L 10+3930$ are in complete LD $\left(\left|\mathrm{D}^{\prime}\right|=1\right) . G C+27279,+31417$ and +31428 are in complete LD, and $M C P 1-2518$ and -2076 are also in complete LD. Rare haplotypes of CCR3 ( $<0.03$ of frequency) were excluded from further analysis.

Haplotypes were constructed by an algorithm developed by Stephens et al. (Stephens et al. 2001). ILIO ht1 and ht3 are equivalent to $I L 10-592$ and $I L 10+3930$, respectively. GC $h t 2$, $h t 3$ and $h t 4$ are equivalent to $G C+31428, G C+31417$ and $G C+27279$, respectively, and MCP1 htl and ht3 are equivalent to MCP1 -2518 and MCP1 -2076, respectively. Haplotypes with either equivalence with a single polymorphism or with frequencies less than $3 \%$ were excluded inform the statistical analysis.

lower bone mass, the majority of the variation in the bone mineral density (BMD) might be genetically controlled (Kanis et al., 1994; Eisman, 1999). BMD is the major factor determining bone strength and, consequently, osteoporotic fracture risk, and can be considered a quantitative polygenic trait. It has been shown that several genes are associated with BMD, although conflicting results also exist (Kanis et al., 1994; Morrison et al., 1994; Kobayashi et al., 1996; Murray et al., 1997; Keen et al., 1998; Eisman, 1999; Yamada et al., 2001; Arko et al., 2002; Garcia-Giralt et al., 2002).

IL10 is a powerful $\mathrm{T}_{\mathrm{H}} 2$-cell cytokine, and the MCP gene family is a beta-chemokine that binds primarily to C-C chemokine receptors, such as CCR2 or CCR3. CCR3 is a beta-chemokine receptor abundant on eosinophils, mast cells, basophils and a subset of $\mathrm{T}_{\mathrm{H}}$ 2-like T-lymphocytes, and most of the action of beta-chemokines is mediated through the CCR3 receptor (Combadiere et al., 1995; Garcia-Zepeda et al., 1996; Heath et al., 1997). GC was a potential candidate for association with BMD because of its function in vitamin D binding. A plausible relation of these genes (IL10, CCR3, GC, $M C P 1$ and $M C P 2$ ) and their polymorphisms with BMD has been proposed, although there was no direct evidence, so is still controversial. In the present study, by screening 14 SNPs in five candidate genes, including IL1O, CCR3, MCP1, MCP2 and $G C, I L 10-592 A>C$, and a common ILIO haplotype, and IL10 ht2, which is also common in Caucasians (0.29, $\mathrm{n}=1,813)$ and African Americans $(0.41, \mathrm{n}=858)$ (Shin et al., 2000), were observed to be associated with decreased BMD in Korean postmenopausal women. ILIO polymorphisms, which have been reported to be related with IL10 expression and transcriptional activity, may be an important genetic factor in BMD. IL10, produced mainly by macrophages, work as a potent immunosuppressive cytokine by down-regulating the expressions of $\mathrm{T}_{\mathrm{H}} 1$ cytokines and co-stimulatory molecules (Redpath et al., 2001). The two SNPs, IL1O -1082 T>C and $-592 A>C$, contributing to ILIO ht2 were particularly interesting because several previous reports have demonstrated quantitative differences in IL10 transcription 
Table 4. Linkage disequilibrium coefficients $\left(\left|\mathrm{D}^{\prime}\right|\right)$ between the SNP loci in the IL10, CCR3, MCP1 and GC genes.

\begin{tabular}{|c|c|c|c|c|c|}
\hline \multirow{2}{*}{$\frac{\text { Gene }}{\text { IL10 }}$} & \multirow[t]{2}{*}{ Polymorphisms } & \multicolumn{4}{|c|}{ Linkage disequilibrium coefficients $\left(\left|\mathrm{D}^{\prime}\right|\right)$} \\
\hline & & $-1082 A>G$ & $-819 T>C$ & $-592 A>C$ & $+3930 T>C$ \\
\hline & $-1082 A>G$ & - & 1 & 1 & 1 \\
\hline & $-819 T>C$ & & - & 1 & 1 \\
\hline & $-592 A>C$ & & & - & 1 \\
\hline & $+3930 T>C$ & & & & - \\
\hline$C C R 3$ & & $-22557 G>A$ & $-520 T>G$ & $-174 C>T$ & $+51 T>C(Y 17 Y)$ \\
\hline & $-22557 G>A$ & - & 0.799 & 0.968 & 0.981 \\
\hline & $-520 T>G$ & & - & 1 & 0.997 \\
\hline & $-174 C>T$ & & & - & 1 \\
\hline & $+51 T>C(Y 17 Y)$ & & & & - \\
\hline$M C P 1$ & & $-2518 G>A$ & $-2076 A>T$ & & \\
\hline & $-2518 G>A$ & - & 1 & & \\
\hline & $-2076 A>T$ & & - & & \\
\hline$G C$ & & $\begin{array}{c}+27279 T>C \\
(C 283 C)\end{array}$ & $\begin{array}{c}+31417 T>G \\
(D 416 E)\end{array}$ & $\begin{array}{c}+31428 C>A \\
(T 420 K)\end{array}$ & \\
\hline & $+27279 T>C(C 283 C)$ & - & 1 & 1 & \\
\hline & $+31417 T>G(D 416 E)$ & & - & 1 & \\
\hline & $+31428 C>A(T 420 K)$ & & & - & \\
\hline
\end{tabular}

Linkage disequilibrium coefficients $\left(\left|\mathrm{D}^{\prime}\right|\right)$ were calculated between all pairs of biallelic loci (Hedrick and Kumar 2001; Hedrick 1987). IL10 $819 T>C$ and ILIO $-592 A>C$ are related by absolute LD $\left(\mathrm{r}^{2}=1\right)$

and/or expression mediated by alternative alleles or haplotypes. It has been reported that the differences in nuclear-binding activity and IL10 production were mediated by the IL10 $-592 A>C$ (Shin et al., 2000) and ILIO - 1082A $>G$ polymorphisms (Turner et al., 1997; Rees et al., 2002) and the IL1O promoter haplotype (Crawley et al., 1999; Edwards-Smith et al., 1999; Zhang et al., 2002). Among the haplotypes, ILIO ht 2 was associated with an increase in IL10 production, and positive associations with several diseases have also been detected: AIDS progression (Shin et al., 2000), $\mathrm{HCV}$ infection and resistance to antiviral therapy (EdwardsSmith et al., 1999; Yee et al., 2001; Vidigal et al., 2002), advanced alcoholic liver disease (Grove et al., 2000), EBV infection (Helminen et al., 2001), gastric cancer (Wu et al., 2002), cervical cancer (Stanczuk et al., 2001), multiple myeloma (Zheng et al., 2001) and cutaneous malignant melanoma (Howell et al., 2001). Because the roles of IL10 in these diseases suggest that ILIO polymorphisms play a critical role in immunity, inflammation progress and cancer development, by modulating IL10 production, it might also be proposed that the change in IL10 levels by two IL10 polymorphisms was due to the decreased BMD in this study. However it is unclear which polymorphisms are due to the suggestive associations with BMD, as two IL10 polymorphisms (IL10 -592A > C \& IL10 ht2) share a 91\% distribution (Table 3).

In summary, ILIO $-592 A>C$ and/or IL1O ht 2 among the polymorphisms tested in the five-candidate genes, including
IL10, CCR3, MCP1, MCP2 and GC, showed an association with decreased BMD in Korean postmenopausal women. Additional study might need to be followed-up in a more powerful cohort. There is also a need to clarify whether the inhibition of innate immunity by increased IL10 production in ILIO $-592 A>C$ and ILIO ht 2 bearing individuals accelerates the loss of bone mineral density (BMD).

Acknowledgments This work was supported by grant number: M1-0302-00-0073, of the National Research Lab. Program as part of the National Research and Development Program from the Ministry of Science and Technology of Korea.

\section{References}

Adebanjo, O. A., Moonga, B. S., Haddad, J. G., Huang, C. L. and Zaidi, M. (1998) A possible new role for vitamin D-binding protein in osteoclast control: inhibition of extracellular $\mathrm{Ca}^{2+}$ sensing at low physiological concentrations. Biochem. Biophys. Res. Commun. 249, 668-671.

Arden, N. K. and Spector, T. D. (1997) Genetic influences on muscle strength, lean body mass, and bone mineral density: a twin study. J. Bone Miner. Res. 12, 2076-2081.

Arko, B., Prezelj, J., Komel, R., Kocijancic, A., Hudler, P. and Marc, J. (2002) Sequence variations in the osteoprotegerin gene promoter in patients with postmenopausal osteoporosis. J. Clin. 
Table 5. Regression analysis of spinal BMD of patients with SNPs and haplotypes in the IL10, CCR3, MCP1, MCP2 and GC genes in Korean postmenopausal women

\begin{tabular}{|c|c|c|c|c|c|c|c|}
\hline \multirow{2}{*}{ Gene } & \multirow{2}{*}{ Locus } & \multicolumn{3}{|c|}{$\mathrm{N}($ mean $\pm \mathrm{SD})$} & \multicolumn{3}{|c|}{$\mathrm{P}$} \\
\hline & & $\mathrm{C} / \mathrm{C}^{*}$ & $\mathrm{C} / \mathrm{R}^{*}$ & $\mathrm{R} / \mathrm{R}^{*}$ & Co-dominant & Dominant & Recessive \\
\hline \multirow[t]{5}{*}{ IL10 } & $-1082 A>G$ & $305(0.84 \pm 0.17)$ & $57(0.84 \pm 0.17)$ & $4(0.76 \pm 0.21)$ & 0.84 & 0.97 & 0.50 \\
\hline & $-592 A>C$ & $177(0.85 \pm 0.18)$ & $148(0.84 \pm 0.15)$ & $38(0.78 \pm 0.16)$ & 0.02 & 0.06 & 0.03 \\
\hline & $+3930 T>C$ & $339(0.84 \pm 0.16)$ & $27(0.85 \pm 0.17)$ & $1(0.57 \pm 0.00)$ & 0.92 & 0.98 & 0.49 \\
\hline & $h t 2$ & $221(0.85 \pm 0.17)$ & $116(0.83 \pm 0.16)$ & $20(0.79 \pm 0.12)$ & 0.03 & 0.04 & 0.20 \\
\hline & $h t 4$ & $321(0.84 \pm 0.16)$ & $36(0.84 \pm 0.17)$ & . & 0.93 & 0.93 & . \\
\hline \multirow[t]{8}{*}{ CCR3 } & $-22557 G>A$ & $201(0.83 \pm 0.17)$ & $139(0.84 \pm 0.15)$ & $27(0.85 \pm 0.17)$ & 0.87 & 0.84 & 0.99 \\
\hline & $-520 T>G$ & $131(0.83 \pm 0.16)$ & $178(0.85 \pm 0.17)$ & $61(0.83 \pm 0.17)$ & 0.99 & 0.51 & 0.38 \\
\hline & $-174 C>T$ & $146(0.83 \pm 0.16)$ & $179(0.85 \pm 0.17)$ & $45(0.82 \pm 0.18)$ & 0.58 & 0.21 & 0.45 \\
\hline & $+51 T>C(Y 17 Y)$ & $341(0.84 \pm 0.17)$ & $28(0.81 \pm 0.14)$ & . & 0.13 & 0.13 & . \\
\hline & $h t 1$ & $58(0.82 \pm 0.17)$ & $174(0.85 \pm 0.16)$ & $129(0.83 \pm 0.16)$ & 0.88 & 0.29 & 0.56 \\
\hline & $h t 2$ & $217(0.84 \pm 0.17)$ & $127(0.83 \pm 0.15)$ & $17(0.90 \pm 0.18)$ & 0.49 & 0.80 & 0.18 \\
\hline & $h t 3$ & $270(0.84 \pm 0.16)$ & $84(0.85 \pm 0.17)$ & $7(0.69 \pm 0.17)$ & 0.63 & 0.99 & 0.10 \\
\hline & $h t 4$ & $334(0.84 \pm 0.17)$ & $27(0.81 \pm 0.14)$ & . & 0.16 & 0.16 & . \\
\hline \multirow[t]{3}{*}{$M C P 1$} & $-2518 G>A$ & $139(0.82 \pm 0.15)$ & $102(0.84 \pm 0.16)$ & $51(0.87 \pm 0.21)$ & 0.09 & 0.13 & 0.19 \\
\hline & $-2076 A>T$ & $312(0.83 \pm 0.15)$ & $41(0.88 \pm 0.23)$ & $2(0.68 \pm 0.17)$ & 0.14 & 0.07 & 0.26 \\
\hline & $h t 2$ & $163(0.82 \pm 0.17)$ & $92(0.85 \pm 0.16)$ & $36(0.85 \pm 0.19)$ & 0.32 & 0.26 & 0.66 \\
\hline$M C P 2$ & $+1311 A>C(K 46 Q)$ & $192(0.83 \pm 0.17)$ & $139(0.84 \pm 0.16)$ & $33(0.86 \pm 0.15)$ & 0.67 & 0.67 & 0.81 \\
\hline \multirow[t]{4}{*}{$G C$} & $+27279 T>C(C 283 C)$ & $293(0.84 \pm 0.17)$ & $70(0.84 \pm 0.16)$ & $5(0.81 \pm 0.15)$ & 1.00 & 0.89 & 0.62 \\
\hline & $+31417 T>G(D 416 E)$ & $185(0.85 \pm 0.18)$ & $122(0.83 \pm 0.15)$ & $20(0.85 \pm 0.13)$ & 0.96 & 0.66 & 0.44 \\
\hline & $+31428 C>A(T 420 K)$ & $173(0.83 \pm 0.16)$ & $76(0.85 \pm 0.18)$ & $22(0.86 \pm 0.16)$ & 0.55 & 0.64 & 0.55 \\
\hline & $h t 1$ & $99(0.84 \pm 0.15)$ & $115(0.84 \pm 0.16)$ & $39(0.84 \pm 0.18)$ & 0.93 & 0.97 & 0.74 \\
\hline
\end{tabular}

${ }^{*} \mathrm{C} / \mathrm{C}, \mathrm{C} / \mathrm{R}$ and $\mathrm{R} / \mathrm{R}$ represent homozygotes for common allele $(\mathrm{C} / \mathrm{C})$, heterozygotes $(\mathrm{C} / \mathrm{R})$ and homozygotes for rare allele (R/R). Genotype and haplotype distributions, means and standard deviations (SD) of spinal BMDs and $P$ values of three alternative analyzing models (co-dominant, dominant and recessive) for regression analyses are shown. Spinal BMD was adjusted for age, YSM and BMI as covariables.

Endocrinol. Metab. 87, 4080-4084.

Asseman, C. and Powrie, F. (1998) Interleukin 10 is a growth factor for a population of regulatory T cells. Gut 42, 157-158.

Combadiere, C., Ahuja, S. K. and Murphy, P. M. (1995) Cloning and functional expression of a human eosinophil CC chemokine receptor. J. Biol. Chem. 270, 16491-16494.

Crawley, E., Kay, R., Sillibourne, J., Patel, P., Hutchinson, I. and Woo, P. (1999) Polymorphic haplotypes of the interleukin-10 5' flanking region determine variable interleukin-10 transcription and are associated with particular phenotypes of juvenile rheumatoid arthritis. Arthritis Rheum. 42, 1101-1108.

de Waal Malefyt, R., Yssel, H., Roncarolo, M. G., Spits, H. and de Vries, J. E. (1992) Interleukin-10. Curr. Opin. Immunol. 4, 314-320.

Edwards-Smith, C. J., Jonsson, J. R., Purdie, D. M., Bansal, A., Shorthouse, C. and Powell, E. E. (1999) Interleukin-10 promoter polymorphism predicts initial response of chronic hepatitis $\mathrm{C}$ to interferon alfa. Hepatology 30, 526-530.

Eisman, J. A. (1999) Genetics of osteoporosis. Endocr. Rev. 20, 788-804.
Eriksson, C., Eneslatt, K., Ivanoff, J., Rantapaa-Dahlqvist, S. and Sundqvist, K. G. (2003) Abnormal expression of chemokine receptors on T-cells from patients with systemic lupus erythematosus. Lupus 12, 766-774.

Eskdale, J., McNicholl, J., Wordsworth, P., Jonas, B., Huizinga, T., Field, M. and Gallagher, G. (1998) Interleukin-10 microsatellite polymorphisms and IL-10 locus alleles in rheumatoid arthritis susceptibility. Lancet 352, 1282-1283.

Fukunaga, K., Asano, K., Mao, X. Q., Gao, P. S., Roberts, M. H., Oguma, T., Shiomi, T., Kanazawa, M., Adra, C. N., Shirakawa, T., Hopkin, J. M. and Yamaguchi, K. (2001) Genetic polymorphisms of CC chemokine receptor 3 in Japanese and British asthmatics. Eur. Respir. J. 17, 59-63.

Garcia-Giralt, N., Nogues, X., Enjuanes, A., Puig, J., Mellibovsky, L., Bay-Jensen, A., Carreras, R., Balcells, S., Diez-Perez, A. and Grinberg, D. (2002) Two new single-nucleotide polymorphisms in the COL1A1 upstream regulatory region and their relationship to bone mineral density. J. Bone Miner. Res. 17, 384-393.

Garcia-Zepeda, E. A., Combadiere, C., Rothenberg, M. E., Sarafi, 
M. N., Lavigne, F., Hamid, Q., Murphy, P. M. and Luster, A. D. (1996) Human monocyte chemoattractant protein (MCP)-4 is a novel CC chemokine with activities on monocytes, eosinophils, and basophils induced in allergic and nonallergic inflammation that signals through the $\mathrm{CC}$ chemokine receptors (CCR)-2 and -3. J. Immunol. 157, 5613-5626.

Groux, H., O'Garra, A., Bigler, M., Rouleau, M., Antonenko, S., de Vries, J. E. and Roncarolo, M. G. (1997) A CD4+ T-cell subset inhibits antigen-specific T-cell responses and prevents colitis. Nature 389, 737-742.

Grove, J., Daly, A. K., Bassendine, M. F., Gilvarry, E. and Day, C. P. (2000) Interleukin 10 promoter region polymorphisms and susceptibility to advanced alcoholic liver disease. Gut 46, 540545.

Heath, H., Qin, S., Rao, P., Wu, L., LaRosa, G., Kassam, N., Ponath, P. D. and Mackay, C. R. (1997) Chemokine receptor usage by human eosinophils. The importance of CCR3 demonstrated using an antagonistic monoclonal antibody. $J$. Clin. Invest. 99, 178-184.

Hedrick, P. and Kumar, S. (2001) Mutation and linkage disequilibrium in human mtDNA. Eur. J. Hum. Genet. 9, 969972.

Hedrick, P. W. (1987) Gametic disequilibrium measures: proceed with caution. Genetics 117, 331-341.

Hellier, S., Frodsham, A. J., Hennig, B. J., Klenerman, P., Knapp, S., Ramaley, P., Satsangi, J., Wright, M., Zhang, L., Thomas, H. C., Thursz, M. and Hill, A. V. (2003) Association of genetic variants of the chemokine receptor CCR5 and its ligands, RANTES and MCP-2, with outcome of $\mathrm{HCV}$ infection. Hepatology 38, 1468-1476.

Helminen, M. E., Kilpinen, S., Virta, M. and Hurme, M. (2001) Susceptibility to primary Epstein-Barr virus infection is associated with interleukin-10 gene promoter polymorphism. $J$. Infect. Dis. 184, 777-780.

Howell, W. M., Turner, S. J., Bateman, A. C. and Theaker, J. M. (2001) IL-10 promoter polymorphisms influence tumour development in cutaneous malignant melanoma. Genes Immun. 2, 25-31.

Kanis, J. A., Melton, L. J. 3rd, Christiansen, C., Johnston, C. C. and Khaltaev, N. (1994) The diagnosis of osteoporosis. J. Bone Miner. Res. 9, 1137-1141.

Keen, R. W., Woodford-Richens, K. L., Lanchbury, J. S. and Spector, T. D. (1998) Allelic variation at the interleukin-1 receptor antagonist gene is associated with early postmenopausal bone loss at the spine. Bone 23, 367-371.

Kim, M. H., Kim, H. J., Choi, J. Y. and Nahm, D. S. (2003) Transforming growth factor-beta3 gene SfaN1 polymorphism in Korean nonsyndromic cleft lip and palate patients. J. Biochem. Mol. Biol. 36, 533-537.

Kobayashi, S., Inoue, S., Hosoi, T., Ouchi, Y., Shiraki, M. and Orimo, H. (1996) Association of bone mineral density with polymorphism of the estrogen receptor gene. J. Bone Miner. Res. 11, 306-311.

Moore, K. W., O'Garra, A., de Waal Malefyt, R., Vieira, P. and Mosmann, T. R. (1993) Interleukin-10. Аnпu. Rev. Immunol. 11, 165-190.

Morrison, N. A., Qi, J. C., Tokita, A., Kelly, P. J., Crofts, L., Nguyen, T. V., Sambrook, P. N. and Eisman, J. A. (1994) Prediction of bone density from vitamin D receptor alleles. Nature 367, 284-287.
Morrison, N. A., Yeoman, R., Kelly, P. J. and Eisman, J. A. (1992) Contribution of trans-acting factor alleles to normal physiological variability: vitamin $\mathrm{D}$ receptor gene polymorphism and circulating osteocalcin. Proc. Natl. Acad. Sci. USA 89, 6665-6669.

Murray, R. E., McGuigan, F., Grant, S. F., Reid, D. M. and Ralston, S. H. (1997) Polymorphisms of the interleukin-6 gene are associated with bone mineral density. Bone 21, 89-92.

Owens, J. M., Gallagher, A. C. and Chambers, T. J. (1996) IL-10 modulates formation of osteoclasts in murine hemopoietic cultures. J. Immunol. 157, 936-940.

Rapado, A., Hawkins, F., Sobrinho, L., Diaz-Curiel, M., GalvaoTelles, A., Arver, S., Melo Gomes, J., Mazer, N., Garcia e Costa, J., Horcajada, C., Lopez-Gavilanes, E., Mascarenhas, M., Papapietro, K., Lopez Alvarez, M. B., Pereira, M. C., Martinez, G., Valverde, I., Garcia, J. J., Carballal, J. J. and Garcia, I. (1999) Bone mineral density and androgen levels in elderly males. Calcif. Tissue Int. 65, 417-421.

Redpath, S., Ghazal, P. and Gascoigne, N. R. (2001) Hijacking and exploitation of IL-10 by intracellular pathogens. Trends Microbiol. 9, 86-92.

Rees, L. E., Wood, N. A., Gillespie, K. M., Lai, K. N., Gaston, K. and Mathieson, P. W. (2002) The interleukin-10-1082 G/A polymorphism: allele frequency in different populations and functional significance. Cell Mol. Life Sci. 59, 560-569.

Roth, I., Corry, D. B., Locksley, R. M., Abrams, J. S., Litton, M. J. and Fisher, S. J. (1996) Human placental cytotrophoblasts produce the immunosuppressive cytokine interleukin 10. J. Exp. Med. 184, 539-548.

Schunck, B., Kraft, W. and Truyen, U. (1995) A simple touchdown polymerase chain reaction for the detection of canine parvovirus and feline panleukopenia virus in feces. J. Virol. Methods 55, 427-433.

Shin, H. D., Winkler, C., Stephens, J. C., Bream, J., Young, H., Goedert, J. J., O'Brien, T. R., Vlahov, D., Buchbinder, S., Giorgi, J., Rinaldo, C., Donfield, S., Willoughby, A., O'Brien, S. J. and Smith, M. W. (2000) Genetic restriction of HIV-1 pathogenesis to AIDS by promoter alleles of IL10. Proc. Natl. Acad. Sci. USA 97, 14467-14472.

Slemenda, C. W., Christian, J. C., Williams, C. J., Norton, J. A. and Johnston, C. C. Jr. (1991) Genetic determinants of bone mass in adult women: a reevaluation of the twin model and the potential importance of gene interaction on heritability estimates. J. Bone Miner. Res. 6, 561-567.

Stanczuk, G. A., Sibanda, E. N., Perrey, C., Chirara, M., Pravica, V., Hutchinson, I. V. and Tswana, S. A. (2001) Cancer of the uterine cervix may be significantly associated with a gene polymorphism coding for increased IL-10 production. Int. J. Cancer. 94, 792-794.

Stephens, M., Smith, N. J. and Donnelly, P. (2001) A new statistical method for haplotype reconstruction from population data. Am. J. Hum. Genet. 68, 978-989.

Stewart, T. L. and Ralston, S. H. (2000) Role of genetic factors in the pathogenesis of osteoporosis. J. Endocrinol. 166, 235-245.

Szalai, C., Kozma, G. T., Nagy, A., Bojszko, A., Krikovszky, D., Szabo, T. and Falus, A. (2001) Polymorphism in the gene regulatory region of MCP-1 is associated with asthma susceptibility and severity. J. Allergy Clin. Immunol. 108, 375381.

Turner, D. M., Williams, D. M., Sankaran, D., Lazarus, M., 
Sinnott, P. J. and Hutchinson, I. V. (1997) An investigation of polymorphism in the interleukin-10 gene promoter. Eur. $J$. Immunogenet. 24, 1-8.

Van Vlasselaer, P., Borremans, B., Van Den Heuvel, R., Van Gorp, U. and de Waal Malefyt, R. (1993) Interleukin-10 inhibits the osteogenic activity of mouse bone marrow. Blood 82, 23612370.

Van Vlasselaer, P., Borremans, B., van Gorp, U., Dasch, J. R. and De Waal-Malefyt, R. (1994) Interleukin 10 inhibits transforming growth factor-beta (TGF-beta) synthesis required for osteogenic commitment of mouse bone marrow cells. $J$. Cell Biol. 124, 569-577.

Vidigal, P. G., Germer, J. J. and Zein, N. N. (2002) Polymorphisms in the interleukin-10, tumor necrosis factoralpha, and transforming growth factor-betal genes in chronic hepatitis $\mathrm{C}$ patients treated with interferon and ribavirin. $J$. Hepatol. 36, 271-277.

Vreeland, W. N., Meagher, R. J. and Barron, A. E. (2002) Multiplexed, high-throughput genotyping by single-base extension and end-labeled free-solution electrophoresis. Anal. Chem. 74, 4328-4333.

Wanidworanun, C. and Strober, W. (1993) Predominant role of tumor necrosis factor-alpha in human monocyte IL-10 synthesis. J. Immunol. 151, 6853-6861.

Wu, M. S., Huang, S. P., Chang, Y. T., Shun, C. T., Chang, M. C., Lin, M. T., Wang, H. P. and Lin, J. T. (2002) Tumor necrosis factor-alpha and interleukin-10 promoter polymorphisms in Epstein-Barr virus-associated gastric carcinoma. J. Infect. Dis.
185, 106-109.

Yamada, Y., Miyauchi, A., Takagi, Y., Tanaka, M., Mizuno, M. and Harada, A. (2001) Association of the C-509-->T polymorphism, alone of in combination with the T869-->C polymorphism, of the transforming growth factor-betal gene with bone mineral density and genetic susceptibility to osteoporosis in Japanese women. J. Mol. Med. 79, 149-156.

Yee, L. J., Tang, J., Gibson, A. W., Kimberly, R., Van Leeuwen, D. J. and Kaslow, R. A. (2001) Interleukin 10 polymorphisms as predictors of sustained response in antiviral therapy for chronic hepatitis C infection. Hepatology 33, 708-712.

Young, D., Hopper, J. L., Nowson, C. A., Green, R. M., Sherwin, A. J., Kaymakci, B., Smid, M., Guest, C. S., Larkins, R. G. and Wark, J. D. (1995) Determinants of bone mass in 10- to 26-year-old females: a twin study. J. Bone Miner. Res. 10, 558567.

Zhang, J., Chen, H., Hu, L., Fu, J., Zhang, H. and Chen, Y. (2002) Correlation between polymorphism of IL-4 and IL-10 gene promoter and childhood asthma and their impact upon cytokine expression. Zhonghua Yi Xue Za Zhi 82, 114-118.

Zhang, J. and Li, K. (2003) On-off regulation of 3' exonuclease excision to DNA polymerization by Exo+ polymerase. $J$. Biochem. Mol. Biol. 36, 525-528.

Zheng, C., Huang, D., Liu, L., Wu, R., Bergenbrant Glas, S., Osterborg, A., Bjorkholm, M., Holm, G., Yi, Q. and Sundblad, A. (2001) Interleukin-10 gene promoter polymorphisms in multiple myeloma. Int. J. Cancer 95, 184-188. 